\title{
Analysis of the Use of Kindergarten Watching Siaga Bencana Learning Model for Structured Positive Thinking Ability on Early Childhood
}

\author{
Lina Amelia ${ }^{1}$, Fitriah Hayati $^{2}$, Sri Milfayetti $^{3}$, Ichsan $^{4}$ \\ ${ }^{1,2}$ STKIP Bina Bangsa Getsempena Banda Aceh, Indonesia \\ ${ }^{3}$ Universitas Negeri Medan, Indonesia \\ ${ }^{4}$ Politeknik Aceh, Indonesia \\ lina.smartest@gmail.com
}

\begin{abstract}
The Kindergarten Watching Siaga Bencana Learning Model for early childhood has been tested for 2 years in three schools using development research methods. Urgenci of this research is to provide knowledge and skills to young children in dealing with disasters, especially the earthquake and tsunami. In this study children will be taught through a scientific approach to posture (scientific positive and structured thinking). Realizing learning in accordance with the stages of growth and development of early childhood. This research approach uses the research and development $(R \& D)$ method of the Thiagarajan model which consists of 4 stages known as the 4-D model (Four-D model). These stages are the defining stage (Define), the design stage (Design), the development stage (Develop), and the Disseminate stage. the study was conducted over 2 years with details: the first year was the defining stage (Define) and the design stage (Design). The second year was implemented the development stage (Develop), and the Deployment stage (Disseminate). By year 1 it had been reached the model's definition and design stages. The defining stage (Define) is complete, the design stage (Design) model with the following stage summary:1) has been analyze the geographical environmental conditions of the child is associated with earthquake disasters and relevant intelligence theories is completed with the obtainance of the initial trial site of TK syeikh abdurrauf area Blang Oi located about $1.9 \mathrm{KM}$ from the seashore of ulhele, 2) Analysis of learner to draft learning previews, identify key parts to be taught and systematically compose topics to be taught, task analysis and learning purpose specifications, design prototype learning devices (test drafting, media selection and manufacture, format selection, drafting activity implementation procedures are complete. In the second year, the team has come to the field, namely 3 schools. This article will discuss the use of the Kindergarten Watching Siaga Bencana Learning Model in practicing positive and structured thinking skills in early childhood. The description of the results of the analysis each step applied in this model can train the ability to think positively and structured children. Starting from the provision of knowledge through school environment surveys, then mapping in the form of mini models and presenting them. This positive structured thinking can also be trained in the provision of knowledge and skills about earthquakes and tsunamis to children, namely at the micro and macro simulation stages of the earthquake and tsunami.
\end{abstract}

Keywords : Kindergarten Watching; Siaga Bencana; early childhood; positive thinking structured.

\section{Introduction}

Early childhood is a community that is vulnerable to becoming victims when natural disasters occur. Another aspect is that in terms of the potential the child has, the child's early childhood is known as the golden age. The condition of children who have extraordinary potential is suitable to be introduced to disaster preparedness learning. In the next 5 (five) years, disasters will increase with the following problems: increasingly dynamic geological 
phenomena, increasingly extreme climate change, increased environmental degradation, demographic bonuses that are not managed properly. Based on the 2013 Indonesian Disaster Risk Index, the number of people exposed to potential disasters is 205 million people. Based on the results of the evaluation of disaster management in Indonesia in the last 5 (five) years of the National Assessment Report (NAR) 2013 identified the following obstacles: (1) coordination in raising awareness of vulnerable communities; (2) vertical (central and regional) policy synchronization; (3) disaster risk reduction (DRR) has not become a strategic issue of the Government; (4) uncertainty of regional disaster management budget; (6) weak law enforcement related to disaster management (2015-2019: 2 RNPB).

Supporting the 2015-2019 National Disaster Management Plan (RNPB) in terms of raising awareness of vulnerable communities, it is necessary to experience knowledge of disaster preparedness as early as possible for early childhood in disaster prone areas. Another factor that supports the idea of developing a disaster preparedness learning model for early childhood in Banda Aceh city is because Aceh is a disaster-prone area, especially the earthquake and tsunami. Banda Aceh city is flanked by two active fault faults of Sumatra. This fracture is the Aceh segment (part of the Sumatra fault) and the Seulimeum segment. The earthquake threat from these two faults cannot be predicted. Syiah Kuala University Tsunami Disaster Mitigation Research Center researcher Mukhsin Umar said that with this condition, Aceh became an earthquake-prone area (coil 2019).

Another thing that becomes a consideration of the need to develop a model of disaster preparedness learning for young children is the commitment of the Indonesian people to the framework of the 2015-2030 DRR action in the Sendai Framework for Disaster Risk Reduction (SFDRR). There is a global commitment that needs to be reduced to commitments and policies at the local level so that the achievement of DRR in the community can be felt significantly. Valuable learning in HFA that needs to be a reference in implementing SFDRR is:

1. The key to successful national policy implementation is to support concrete action at the community level.

2. The success of national policies in strengthening resilience at the community level depends on policies that are tailored to the specific needs, capacities and vulnerabilities of the community, understanding different risks at the community level, how risks are accepted and prioritized by different economic - social groups.

3. The combination of the state and grassroots approach with the involvement of government and non-government actors offers sustainable solutions that are the most cost-effective (with an open, inclusive, local nature, builds local capacity and values local knowledge).

The world of education is one suitable place for the implementation of the DRR 20152030 action framework in the Sendai Framework for Disaster Risk Reduction (SFDRR) point 1 which states that the key to successful national policy implementation is to support concrete actions at the community level. This is very ironic because PAUD schools are the basis of a community of children who are vulnerable groups that need to be protected and simultaneously need to be improved in their knowledge and skills. PAUD schools are the basis of the children's community. They are parties that must be protected and at the same time need to increase their disaster knowledge, especially in disaster prone areas such as Aceh. The school is an institution that is trusted by the people of Indonesia to 'entrust' their children. The Child Protection Act number 23 of 2002 mandates the importance of education and special protection for children. Thus, it is the duty of the government and the authorities, as well as competent and caring 
institutions to ensure the fulfillment of these special educational and protection needs. In 2009 the curriculum center of the National Education Ministry's research and development body has published disaster risk reduction modules for elementary / MI, SMP / MTs and SMA / SMK / MA / MAK levels, especially for PAUD still difficult to find sources of earthquake risk reduction learning.

The information above shows that the SSB program has not yet reached PAUD institutions. Thus the Research Development of Kindergarten Watching Siaga Bencana Learning Model in the Context of Providing Education for Disaster Mitigation for Early Childhood in disaster prone areas in Banda Aceh city is very original and very important to do. Because of the lack of information / methods / learning of disaster mitigation for early childhood. Based on several international reference journals / conferences on disaster mitigation in Indonesia it is still difficult to find knowledge and skills for early childhood in particular, but the urgency of providing disaster mitigation education has been carried out in several studies at the 2015 National Tsunami Disaster Mitigation Symposium Aiko Sakurai, Mizan Bustanul Fuady Bisri, Rina Suryani Oktari, Takashi Oda, (2016,) about The 11th Years Assessment on School Safety and Disaster Education at Public Elementary Schools in Banda Aceh after the 2004 Aceh Tsunami: Preliminary Findings. The scope of research is still for elementary school in Banda Aceh. Suhardjo Dradjat (2011: 174-188) in his research concluded that disaster mitigation education in the framework of DRR (Disaster Risk Reduction) as follows:

- Must be done through formal education in the National Education System (Diknas) program with curriculum design from the National Education Standardization Agency (BSNP).

- For informal education channels through the National Disaster Management Agency (BNPB) in collaboration with relevant agencies, for example the Ministry of Home Affairs, the Ministry of Public Works, the Ministry of Health, and the Ministry of Transportation.

- The post-disaster relocation program is the responsibility of the Ministry of Manpower and Transmigration (Nakertrans) in cooperation with the transmigrant origin local government and transmigrant destination governments.

- It is necessary to increase scientific and technological research related to DRR programs with an appropriate technological approach by considering elements of local wisdom.

This research information emphasizes the need to increase science and technology research related to DRR programs with an appropriate technological approach by considering elements of local wisdom. For this reason, it is necessary to have a research design that prioritizes the provision of knowledge and skills for early childhood in disaster mitigation efforts because Aceh is an area classified as having experienced frequent earthquakes in recent years. In the world of children's education there are still very few teaching materials and design learning models that can be applied by PAUD educators in the context of implementing disaster mitigation learning in PAUD institutions.

The purpose of implementing and developing the Kindergarten Watching Siaga Bencana Model in the Context of Providing Early Childhood Disaster Mitigation Education in disasterprone areas in the Banda Aceh city is to reduce the risk of disasters for young children by establishing structured positive thinking skills for early childhood. To realize this goal, every 
step of the model's implementation is strived to bring up the ability to think positively structured in children under the stimulation of the teacher in disaster preparedness learning activities for children while playing. The research conducted is focused on analyzing the use of the Kindergarten Watching Siaga Bencana Learning Model for the Structured Positive Thinking Ability in Early Childhood.

\section{Review of Literature}

\subsection{Early Childhood Education (PAUD)}

Early childhood education is a planned and systematic effort undertaken by educators or caregivers of children aged 0-8 years with the aim that the child is able to develop the potential he has optimally. Marjory Ebbeck (in Hibana, 2005: 3) said "early childhood education is a service for children from birth to the age of eight years." In general, the aim of early childhood education programs is to facilitate overall growth and development of children in accordance with norms and values life held. PAUD is an investment for children in facing their lives in the future. Asmani (2009: 14) says "PAUD is a systematic and effective instrument in efforts to educate children, so they find a golden period that determines their future". Law (Law) Number 20 of 2003 concerning the National Education System has mandated the implementation of education to all Indonesian people from an early age, i.e. since children are born. It is explicitly stated in the law that early childhood education (PAUD) is a coaching effort aimed at children from birth until the age of six carried out through the provision of educational stimuli to help physical and spiritual growth and development so that children have readiness in entering further education (article 1, item 14). Furthermore, it is stated explicitly in Law Number 20 Year 2003 (article 28), among others, that PAUD is held before the level of basic education, and PAUD can be held in formal education channels (such as kindergarten, Raudhatul Athfal or other equivalent forms), education pathways non-formal (such as a daycare center, playgroup, or other equivalent), as well as informal education channels (such as PAUD in the family or organized by the environment).

\subsection{The Kindergarten Watching Siaga Bencana Model Learning}

Kindergarten Watching Siaga Bencana learning model is a disaster mitigation learning model designed for children aged 5-6 years in order to provide knowledge and skills to save themselves from the dangers of the earthquake independently by training children to think properly in the event of a disaster, Feeling directed when no one is adults who direct in an earthquake disaster situation, be alert, act appropriately, and be thoroughly responsible. The development of a kindergarten Siaga Bencana watching learning model in the context of providing disaster mitigation education for early childhood is the adoption and development of the Town Watching method. The town watching method was introduced by Prof. Dr. Ogawa Yujiro in the 2010 Town Watching for Disaster Prevention Guidebook at Fuji Tokoha University. The town watching method is an effort to form a city community that responds to natural disasters including earthquakes. The adoption of the town watching method is a kindergarten watching Siaga Bencana learning model through earthquake simulation games in this study predicted to be suitable for stimulating children's intelligence that will help children master knowledge and saving skills when an earthquake strikes. Amelia (2014: 71-84) is a forerunner of ideas in finding suitable models for the provision of disaster knowledge to early 
childhood. however this research focuses more on learning which has more effect on children's intelligence abilities. but in this study it has been seen that learning with disaster risk reduction content can be done in early childhood education. (2) Amelia (2015: 151) tried to find a formulation of a simpler model for disaster mitigation knowledge in children with very limited scope integrated with the development of 2 early childhood intelligence (visual spatial and kinesthetic). The title of the research is the Use of the Kindergarten Watching Siaga Bencana Method for Earthquake to Stimulate Spatial Visual and Kinesthetic Intelligence in Early Childhood in Kindergarten Abdurrauf Blang Oi Banda Aceh. And Amelia (2015: 26-38) conducted a two-trial study entitled the timulation of Spatial Visual Intelligence and Kinesthetic Intelligence in Early Childhood through the Kindergarten Watching Siaga Bencana Method for Earthquake in the Integrated Paud Permata Hati Banda Aceh. The aim is to find the basic formulation of the formation of kindergarten watching Siaga Bencana models for disaster education.

Finally, before actually establishing a mitigation learning model for early childhood, an environmental needs analysis is conducted. Town watching method has 4 core stages such as Field survey, Develop a map of observation, Discussion to solve the problem, Presentation (Yujiro OGAWA: 2010). The development of a kindergarten watching Siaga Bencana model for in the context of providing disaster mitigation education for young children is the development of the Town Watching method and its implementation in the form of a 2013 curriculum scientific approach.

The steps in kindergarten watching are derived from 4 steps in the town watching method (Field survey, Develop a map of observation, Discussion to solve the problem, Presentation) which is modified according to the ability of children in kindergarten. The 4 steps in the original town watching method are as follows:

1. Field Survey

2. Develop a map of observation

3. Discussion to solve the problem

4. Presentation

From the four core steps above, it will be developed in 7 meetings for early childhood, i.e.

1. School environment survey and identification of dangerous objects

2. Provision of knowledge of earthquakes and tsunamis through animated films

3. Provision of knowledge through concrete mockup media in the form of micro earthquake simulations

4. Making a map of the location of schools through mock imitations of styrofoam

5. Presentation of the path / mock map

6. Survey the path of escape

7. Earthquake rescue simulation (macro / real simulation)

\subsection{Structured Positive Thinking Abilities}

The purpose of developing this learning model is to try to provide knowledge and skills to young children so that they have the ability to act correctly and appropriately in the event of a disaster, especially earthquakes. The ultimate goal of this activity is that children in earthquakeprone areas are accustomed to structured positive thinking (POSTURE) in every given activity. Components of positive thinking that want to be formed are:

1) Think right

2) Feel directed

3) Be alert 
4) Act right

5) Responsible completely

To produce these positive structured thinking habits, the teacher must carry out activities in the Kindergarten Watching Disaster Preparedness learning model by applying:

1) getting used to giving HOTS (High Order Thinking) questions to young children like "have you ever heard the word earthquake? What do you think / feel / imagine if mother mentioned the word earthquake? Etc.

2) Using a scientific approach

a. Observe each media at the beginning of the activity

b. Ask questions that can occur from the teacher to the child, collecting data, reasoning and communicating)

3) The method used to play while learning and learning while playing, the Question and Answer method, and the simulation method.

\section{Research Method}

The research method carried out to analyze the ability of structured positive thinking in early childhood is a qualitative research method. The instruments used were observation sheets, performance and interviews. The study population is children aged 5-6 years from two kindergarten schools in Banda Aceh city namely TKIT Sheikh Abddurrauf Banda Aceh and TK Tunas Bangsa with a population of 80 children. The research sample is the entire population.

\section{Result and Discussion}

Assessment in this model includes 4 aspects of assessment according to the demands of the 2013 PAUD curriculum (Permendikbud no. 146 of 2014) including:

1. Assessment of children's spiritual attitudes will be taught prayer when disaster strikes and Questions and answers about disasters related to religion, what must be done to deal with disasters, the attitude of a child as a religious community in the face of disasters

2. Assessment of social emotional attitudes will be given through singing activities about earthquakes, when carrying out micro earthquake simulation project tasks, the project method of making simple mockups using styrofoam and during micro disaster simulation.

3. An assessment of the mastery of knowledge provided through animated films and mockup media about the concept of space, amount, color and shape, layout and space construction.

4. Assessment of skills acquired by children in the learning model that gives rise to agility during macro simulations and children's ability to communicate the learning experiences gained by children at each stage of model learning.

5. An assessment of the mastery of knowledge provided through animated films and mockup media about the concept of space, amount, color and shape, layout and space construction.

6. Assessment of skills acquired by children in the learning model that gives rise to agility during macro simulations and children's ability to communicate the learning experiences gained by children at each stage of model learning.

In addition to the 4 aspects of the assessment above also observed the child's ability to think positively structured. Components of positive thinking that want to be formed are:

1) Think right 
Thinking right is the child has the concept of knowledge as expected, such as children understand dangerous and harmless objects, a place to save themselves during disasters, understand the concept of earthquake and tsunami and the consequences of both.

2) Feel directed

Children have been able to take decisions in acting armed with the knowledge they have acquired, such as sheltering under a sturdy table when an earthquake is in the room. And will run to an open field after the earthquake subsides and away from trees, buildings and items that will befall him when an earthquake shakes. Run to high ground to avoid tsunami waves.

3) Be alert

Able to provide an explanation of the actions that will be taken in the event of a disaster and this is also seen when children conduct earthquake simulations

4) Act right

This will be seen when the child is playing an earthquake simulation that is running while closing his head and running open

5) Responsible completely

This can be seen from the child's willingness to participate in activities from the beginning to the end so that the child gets the knowledge and skills of self-rescue as a whole.

The results of observations made on 80 children with the help of 12 class teachers and 4 research assistants can be described the results of observations as the table below. Observations with 4 assessment criteria, namely:

1. BB (not yet developed) means that the child works almost up to $75 \%$ of the activities under the instruction of the class teacher

2. MB (Start Developing) means that children work $50 \%$ assisted by the teacher

3. BSH (Developing as Expected) means that children work $25 \%$ need the help of a teacher

4. BSB (Very Good Development) means that children work independently and are almost not assisted by teachers anymore, teachers only supervise their work, only $10-15 \%$ of teacher involvement in each task given.

Recapitulation of observations during the Kindergarten Watching Siaga Bencana Learning Model activity for young children

\begin{tabular}{|c|c|c|c|c|c|c|c|c|c|c|}
\hline \multirow[b]{2}{*}{ NO } & \multirow[b]{2}{*}{ ASPECT } & \multicolumn{2}{|c|}{ BB } & \multicolumn{2}{|c|}{ MB } & \multicolumn{2}{|c|}{ BSH } & \multicolumn{2}{|c|}{ BSB } & \multirow{2}{*}{$\begin{array}{l}\text { POSITIVE } \\
\text { THINKING } \\
\text { ASPECT IS } \\
\text { STRUCTURED }\end{array}$} \\
\hline & & $\mathbf{F}$ & $\%$ & $\mathbf{F}$ & $\%$ & $\mathbf{F}$ & $\%$ & $\mathbf{F}$ & $\%$ & \\
\hline A & $\begin{array}{l}\text { SPIRITUAL } \\
\text { VALUE (KI1) } \\
\end{array}$ & & & & & & & & & \\
\hline 1 & $\begin{array}{l}\text { earthquake is one } \\
\text { form of God's } \\
\text { power. }\end{array}$ & 13 & 16 & 21 & 26 & 26 & 33 & 20 & 25 & RIGHT THINK \\
\hline B & $\begin{array}{l}\text { EMOTIONAL } \\
\text { SOCIAL (KI2) }\end{array}$ & & & & & & & & & \\
\hline 2 & $\begin{array}{l}\text { want to do a micro } \\
\text { simulation }\end{array}$ & 15 & 19 & 18 & 23 & 23 & 29 & 24 & 30 & FEEL FEARING \\
\hline 3 & $\begin{array}{l}\text { want to follow the } \\
\text { rules of play }\end{array}$ & 18 & 23 & 19 & 24 & 33 & 41 & 10 & 13 & FEEL FEARING \\
\hline 4 & $\begin{array}{l}\text { want to work } \\
\text { together to make } \\
\text { imitation mockups }\end{array}$ & 12 & 15 & 22 & 28 & 35 & 44 & 11 & 14 & ACT RIGHT \\
\hline
\end{tabular}




\begin{tabular}{|c|c|c|c|c|c|c|c|c|c|c|}
\hline \multirow{2}{*}{ NO } & \multirow{2}{*}{ ASPECT } & \multicolumn{2}{|c|}{ BB } & \multicolumn{2}{|c|}{ MB } & \multicolumn{2}{|c|}{ BSH } & \multicolumn{2}{|c|}{ BSB } & \multirow{2}{*}{$\begin{array}{l}\text { POSITIVE } \\
\text { THINKING } \\
\text { ASPECT IS } \\
\text { STRUCTURED } \\
\end{array}$} \\
\hline & & $\mathbf{F}$ & $\%$ & $\mathbf{F}$ & $\%$ & $\mathbf{F}$ & $\%$ & $\mathbf{F}$ & $\%$ & \\
\hline 5 & $\begin{array}{l}\text { want to appear } \\
\text { presentations of the } \\
\text { work in the future }\end{array}$ & 14 & 18 & 16 & 20 & 36 & 45 & 14 & 18 & RIGHT THINK \\
\hline 6 & $\begin{array}{l}\text { running calmly } \\
\text { during the } \\
\text { simulation }\end{array}$ & 9 & 11 & 15 & 19 & 38 & 48 & 18 & 23 & ACT RIGHT \\
\hline 7 & $\begin{array}{l}\text { no fuss when } \\
\text { working on mini } \\
\text { model mockups }\end{array}$ & 15 & 19 & 18 & 23 & 30 & 38 & 17 & 21 & $\begin{array}{l}\text { TOTAL } \\
\text { RESPONSIBILITY }\end{array}$ \\
\hline $\mathrm{C}$ & $\begin{array}{l}\text { KNOWLEDGE } \\
\text { AND SKILLS (KI3 } \\
\text { and KI4) }\end{array}$ & & & & & & & & & \\
\hline 8 & $\begin{array}{l}\text { know how to make } \\
\text { mini mockups } \\
\text { according to } \\
\text { instructions }\end{array}$ & 14 & 18 & 24 & 30 & 33 & 41 & 9 & 11 & ACT RIGHT \\
\hline 9 & $\begin{array}{l}\text { able to tell the } \\
\text { purpose of the model } \\
\text { made by children }\end{array}$ & 15 & 19 & 20 & 25 & 37 & 46 & 8 & 10 & FEEL FEARING \\
\hline 10 & $\begin{array}{l}\text { run according to the } \\
\text { rules when macro } \\
\text { simulation }\end{array}$ & 12 & 15 & 18 & 23 & 38 & 48 & 12 & 15 & BE AWAY \\
\hline 11 & $\begin{array}{l}\text { know the symbols of } \\
\text { self-rescue }\end{array}$ & 10 & 13 & 22 & 28 & 37 & 46 & 11 & 14 & BE AWAY \\
\hline 12 & $\begin{array}{l}\text { able to tell the } \\
\text { contents of the } \\
\text { animated film being } \\
\text { watched }\end{array}$ & 13 & 16 & 17 & 21 & 40 & 50 & 10 & 13 & FEEL FEARING \\
\hline 13 & $\begin{array}{l}\text { protect the head } \\
\text { when running }\end{array}$ & 10 & 13 & 21 & 26 & 39 & 49 & 10 & 13 & BE AWAY \\
\hline 14 & $\begin{array}{l}\text { run to open fields } \\
\text { and stay away from } \\
\text { dangerous places }\end{array}$ & 11 & 14 & 22 & 28 & 38 & 48 & 9 & 11 & ACT RIGHT \\
\hline & TOTAL & 181 & 226 & 273 & 341 & 483 & 604 & 183 & 229 & \\
\hline & AVERAGE & 12 & 16 & 20 & 24 & 35 & 43 & 13 & 17 & \\
\hline
\end{tabular}

From the table above it can be seen that children who develop according to expectations and develop very well more than $50 \%$ of the population, namely around 48 children $(60 \%)$ of the entire population. Children who still need additional training time or start to develop around 20 children $(24 \%)$ of the population and children who really need to be re-guided and re-trained in this disaster preparedness learning there are around 12 children $(16 \%)$ of the population. This shows that the Kindergarten Watching Siaga Bencana Learning Model for young children has a positive impact on the 4 core competencies of children, namely spiritual, social emotional competence, children's knowledge and skills. If analyzed in terms of thinking children will follow the observational indicators observed that structured positive thinking has emerged more than $50 \%$ of the population because of the observed indicators have emerged $60 \%$ of children with categories developing according to expectations and developing very 
well. This is also reinforced from the results of interviews with the teacher that the children have memorized the song about the earthquake and when occasionally asked where to run and how to run when an earthquake occurs they are able to answer to an open field with headgear, avoiding glass or shelter in the column of the table. This shows the child has felt directed, introspective and acted appropriately.

\section{References}

Aiko Sakurai, Mizan Bustanul Fuady Bisri, Rina Suryani Oktari, Takashi Oda, 2016, The 11th Years Assessment on School Safety and Disaster Education at the Public Elementary Schools in Banda Aceh after the 2004 Aceh Tsunami: Preliminary Findings, , Simposium Nasional Mitigasi Bencana Tsunami 2015, Banda Aceh, 21-22 Desember 2015, Banda Aceh, TDMRC Unsyiah, , 2477-6440.

Amelia, Lina. 2014. Pengembangan Model Pembelajaran Simulasi Pengurangan Resiko Bencana Gempa Bumi dan Tsunami ( PRB-GT) dalam Menstimulasi Kecerdasan Multiple Intelegensi Anak PAUD di kota Banda Aceh. Jurnal Cemerlang. Vol. 1 No. 1 (71-84)

Amelia, lina., et al 2015. Metode Kindergarten Watching Siaga Bencana Gempa Bumi Terhadap Stimulasi Kecerdasan Visual Spasial Dan Kecerdasan Kinestetik Anak Usia Dini Di TK Syeikh Abdurrauf Blang Oi Banda Aceh. Prosiding conference Counseling Centre Lab. Pendidikan Profesi Konselor Unimed,Bekerjasama Dengan Ikatan Konselor Indonesia serta Saffone Counseling Training \& Consultancy Malaysia. Medan: 21 Maret 2015. Hal 151-157

Amelia, Lina. 2015. Stimulasi Kecerdasan Visual Spasial Dan Kecerdasan Kinestetik Anak Usia Dini Melalui Metode Kindergarten Watching Siaga Bencana Gempa Bumi Di Paud Terpadu Permata Hati Banda Aceh. Jurnal Visipena.Vol. 6 No. 2. Hal 26-39. ( diakses di https://scholar.google.co.id/citations?user=q5hlx8YAAAAJ\&hl=id )

Asmani, Jamal Makmur. 2009. Manajement Strategis Pendidikan Anak Usia Dini. Yogyakarta: Diva Press.

BNPB. 2015. Kerangka Kerja Sendai untuk Pengurangan Risiko Bencana 2015 - 2030 accessed from http://perpustakaan.bappenas.go.id/lontar/file?file=digital/167744[Konten_]-Konten\%20D1935.pdf diakses 28 mei 2018

BNPB. 2014. Rencana Nasional Penanggulangan Bencana 2015-2019. Jakarta

Kumparan. (2019) Banda Aceh Rawan Bencana Gempa, BPBA Imbau Warga Selalu Waspada. https://kumparan.com/@kumparannews/banda-aceh-rawan-bencana-gempa-bpbaimbau-warga-selalu-waspada-1546430437362776697

Permendikbud Nomor 146 Tahun 2014 Tentang Kurikulum 2013 PAUD

UNISDR. 2017. International Strategy for Disaster Reduction: Hyogo Framework for Action 2005 - 2015: Building the Resilience of Nations and Communities to Disasters dalam http://www.unisdr.org/files/1217_HFAbrochureEnglish.pdf. (accessed 27 mei 2018)

Undang-Undang No. 20 tahun 2003 Tentang Sistem Pendidikan. Nasional. Jakarta

Undang-Undang Nomor 23 Tahun 2002 Tentang Perlindungan Anak

Yujiro, Ogawa. 2010. Town Watching for Disaster Prevention Guidebook. Graduate School of Environmental and Disaster Research Fuji Tokoha University. 